\title{
Az egykori szovjet katonai területek funkcióváltása Debrecenben
}

\section{Reuse of former soviet military sites in Debrecen}

\author{
KÁDÁR KRISZTA, KOZMA GÁBOR
}

\section{Bevezetó}

Magyarországon a rendszerváltást követően az ipari termelés visszaesése, a magyar honvédség létszámának csökkenése és a szovjet megszálló csapatok kivonulása következtében nagy mennyiségben váltak feleslegessé ipari és katonai területek. Ezen épületek, területek barnamezőkké, rozsdaövezetekké alakultak, és csak egy részük esetében mondható el, hogy a kiürítést követően rövid időn belül tartósan újrahasznosításra kerültek.

A volt katonai használatú objektumok első tulajdonosai - többnyire az állam és az önkormányzatok - a területek újrahasznosítása során jellegzetes problémákkal küzdöttek és küzdenek ma is. Az ingatlanok környezeti szempontból általában szennyezettek voltak, az épületek jelentős része nem felelt meg a magyar szabványoknak, és ezért szükségessé vált a lebontásuk. A fenti tényezők rendkívül megnehezítették az érintett ingatlanok újrahasznosítását, ami a központi kormányzati pénzek mellett szükségessé tette az önkormányzati és a magánforrások felhasználását is.

A tanulmány célja az egykori szovjet katonai területek funkcióváltásának bemutatása az ország második legnagyobb városa, Debrecen példáján. A település kiválasztását egyrészt az indokolja, hogy a rendszerváltás előtt igen jelentős számú szovjet haderő állomásozott a városban, és az általa használt ingatlanok nagysága tekintélyes, ugyanakkor különböző típusú volt. Másrészt vizsgálataink arra az eredményre juttattak bennünket, hogy az érintett területek újrahasznosítása alapvetően sikeresnek tekinthető, így a város példája más települések számára is hasznosítható tapasztalatokat jelent.

A tanulmány alapvetően három részre osztható. Az első rész a szovjetek ingatlankialakítását, -használatát, kivonulását tekinti át, míg a második Debrecen helyzetét elemzi: egyrészt bemutatja, milyen a város hasznosítatlan

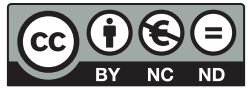


barnamezős helyzete, hogyan kezelték a különböző fejlesztési dokumentumok az egykori szovjet ingatlanok kérdéskörét, másrészt az objektumokat hasznosításuk, jelenlegi helyzetük alapján három fő csoportra osztja. A harmadik részben feltárjuk a debreceni objektumok hasznosításának jellegzetességeit.

\section{A szovjet katonai területek jellemzói és a hasznosítás nehézségei}

Szovjet csapatok a II. világháború során és az 1950-es évek derekán szállták meg az országot, és 47 év után, 1991-ben távoztak. A kialakított (elfoglalt) objektumok adott városba történő telepítésének katonapolitikai indokairól rendkívül kevés információ áll rendelkezésre, aminek az az oka, hogy a csapatkivonást követően megkezdődött ugyan az iratok feldolgozása, de a rendelkezésre álló dokumentumok jórészt a magyar haderőről, annak átalakításáról szólnak.

Csapody Tamás szerint (2000) Magyarország 104 településén, 288 objektumban állomásoztak szovjetek, mintegy 55 ezer fó katona és kb. 50 ezer polgári személy. A VITUKI Kht. által készitett Országos környezeti kármentesitési program tájékoztató összefoglalása szerint (2005) 171 volt szovjet objektum található az országban. Homor György (2009) müvében megemlíti, hogy 1991-ben 100380 szovjet állampolgár hagyta el hazánkat, ezen belül 44668 katona. 94 helyőrség ürült ki, amelyekben összesen 328 ingatlant használtak a szovjetek.

A teljes csapatkivonás kezdete 1990. március 12-hez kötődik, ekkor Hajmáskérről indult a veszprémi harckocsiezred. Az utolsó szovjet katona, Silov altábornagy, 1991. június 16-án hagyta el az országot a záhonyi Tisza-hídon.

A volt szovjet ingatlanok közül 80-90 található megyeszékhelyeken, ez az összes objektum 28-30\%-a. A megyeszékhelyek közül a fövárosban és Kecskeméten helyezkedik el a legtöbb objektum, míg Egerben, Tatabányán és Salgótarjánban nem volt szovjet használatú katonai építmény.

Az 1957-es szovjet-magyar egyezményről szóló törvényerejü rendelet rögzíti, hogy „a szovjet csapatok állomáshelyén épületek, repülőterek (...) építéséhez (...) az illetékes magyar szervek engedélye szükséges. Ugyanilyen engedély szükséges a szovjet csapatok állomáshelyén kívül (...) állandó jellegű építmények létesítéséhez is." A szovjetek a fent idézett rendelet elöirásait gyakran figyelmen kívül hagyták, amikor engedély nélkül, a magyar szabványoktól eltéró, a magyar elöírásoknak semmilyen szempontból nem megfelelő épületeket húztak fel. Mind a korábbi magyar épitésü, mind a szovjet épületek az átvétel idején általában véve igen rossz állapotúak voltak: szemét, lom, hiányzó ajtók, ablakok, befalazott nyilászárók, a viztelenités hiánya miatt elfagyott vezetékek általánosak vol- 
tak. Az ingatlanok már használatuk során számottevő károkat szenvedtek el, de ehhez hozzáadódtak azok a károk is, amelyeket a szovjetek közvetlenül a távozásuk elött okoztak a mozdítható, értékesithető elemek leszakításával, kiásásával, egyes épületek, tárgyak felégetésével.

A volt hadászati használatú, barnamezőkké vált területek újrahasznosítása a dömpingszerüen az ingatlanpiacra zúduló ingatlanok következtében fokozatosan történik 1990 óta. Gondot okoz, hogy a területek sokszor elszórtan helyezkednek el lakóingatlanok, más negyedek közt, kiterjedésük nem fed le teljes városrészeket, így a városképhez illeszkedő egységes rehabilitációs terv kidolgozása és megvalósítása is kevés esetre jellemző.

A problematikusabb területeken az újrahasznosítást elősegítené a területek rendezése, illetve a környék, a közvetlen környezet revitalizálása, vonzóvá tétele a befektetők számára, ami általában jelentős összegeket emészt fel. Ahol a terület előkészítése megtörténik, ott a hasznosítás gyorsabban, gördülékenyebben valósul meg, ami legtöbbször nagymértékben javítja a közvetlen környék megítélését is.

\section{Barnamezók, azon belül volt szovjet katonai ingatlanok átalakulása Debrecenben}

A VÁTI Kht. (2003) barnamezős tanulmánya Debrecent a közepesen nagy (100-200 ha) barnamezős területnagysággal rendelkező városok közé sorolja, ahol 40 hektárnál is nagyobb összefüggő telephely(ek) találhatók. A volt katonai telephelyek nagyságát 11-50 hektár közé teszi, amely jelentősen alábecsült adat, ha tekintetbe vesszük, hogy csak a szovjet ingatlanok több mint 600 hektáron terülnek el.

A város barnamezős területeinek funkcióváltásáról és zöldmezős beruházásairól 2006-ban készült átfogó tanulmány (Győri 2006). Bár 1990 után Debrecenben is jelentősen visszaesett az ipari foglalkoztatottak száma, a városban mindössze két nagyobb ipari barnamezős területet tartottak számon 2000-ben, 170 hektáron. A nyugati ipari zónában a házgyár, gabonasilók, építő- és müanyagipari telephelyek, a délkeleti területen a lakóterületek közé ékelődött könnyü- és élelmiszer-ipari telephelyek találhatók. Szerencsésnek mondható, hogy a telephelyek bezárása nem egyszerre, nagy volumenben következett be, hanem fokozatosan zajlott, ami az újrahasznosításnak kedvezett. Gondot okozott azonban, hogy amikor a nagyvállalatok egy részét felszámolták az 1990-es évek elején, sok esetben a telephelyeket 2-8 részre osztották fel, a telephelyeken a közmüvek, utak osztatlan közös tulajdonba kerültek. Néhány volt ipari területen a régiek helyére újabb vállalkozások települtek, ezek közül sokan megőrizték az eredeti profilt, de van, ahol új tevékenységek jelentek meg. 
A szovjet csapatok 1944-ben érkeztek a városba (Ránki 1976), majd az 1950-es évek második felétől fokozatosan növekedett a létszámuk, és kiszolgálásukra különböző funkciójú épületeket, laktanyákat, lakóházakat, kiképzőközpontokat, raktárakat, gyakorló- és lőtereket építettek. A volt szovjet ingatlanok a város területén szétszórtan helyezkednek el (1. ábra), méretük pedig igen nagy határok között mozog: a legnagyobb meghaladja a 400 hektárt, míg a legkisebb a 1 hektárt sem éri el.

Jóllehet, a volt magyar használatú katonai objektumok újrahasznositása hasonló problémákkal szembesíti a kezelő szerveket, tulajdonosokat, mint a volt szovjet ingatlanoké, jelen tanulmányban ezek sorsáról csak röviden számolunk be. A rendszerváltást követö néhány évben még öt magyar katonai objektum müködött a városban, mára ezekböl csak három funkcionál. A Füredi úton található a Bocskai István Gépesitett Lövészdandár objektuma, a Böszörményi úti egykori szovjet-magyar katonai épületek egy részét még mindig honvédségi ruharaktárként, és a Honvéd utcában hadkiegészitó parancsnokság kapott helyet. A korábban a Magyar Néphadsereg használatában volt Csengö utcai Bocskai laktanya helyén a Nemzeti Adó- és Vámhivatal Észak-alföldi Regionális Adó Főigazgatósága, a KSH Debreceni Igazgatósága, valamint a Kossuth Gimnázium nyert elhelyezést, a Lőtér utcai egykori vasútépitó zászlóalj által használt laktanya azonban lepusztult, romos állapotú.

\section{Az ingatlanok megjelenése a városfejlesztési és tervezési dokumentumokban}

Az elmúlt 20 évben megszületett városfejlesztési elképzeléseket elemezve megállapítható, hogy a dokumentumokban az egykori szovjet ingatlanok külön területi típusként nem jelentek meg, a barnamezős területek mint összefoglaló kategória csak a volt ipari területekre vonatkozott, de a legjelentősebb volt szovjet objektumokat egyedileg megemlítették a fejlesztési dokumentumok egy részében.

A volt üzemi (barnamezős) rehabilitálandó gazdasági területek közé Debrecen településszerkezeti terve (2000) hét ingatlant sorol, ebböl hármat már az első ütemben megvalósítani terveznek: a MÁV-pályaudvart, a délkeleti iparterületet és a délnyugati iparterületet. A Belvároshoz közeli telkek megújulása a tervezők elképzelése szerint Debrecen megitélésén, imázsán javithat, és a város versenyképességét is növeli.

A helyi építési szabályzat és szabályozási terv $(2003,2010)$ a barnamezős, illetve volt katonai használatú ingatlanokról szintén nem tesz említést, de a természetvédelmi területek nagy aránya és a belterületen rendelkezésre álló csekély számú zöldmezös terület miatt igen szük korláto- 
kat szab az új zöldmezős beruházásoknak, így indirekt módon támogatja a barnamezős fejlesztéseket.

Debrecen Megyei Jogú Város 2007-2013 közötti fejlesztésének operatív programja (Euro-Régió Ház 2006) egyrészt „A hatékonyabb gazdaság fejlo"déséhez szükséges feltételek megteremtése" prioritás elso" intézkedésében (A város nemzetközi és országos megközelithetőségének javítása) alapvetö fontosságúnak tekinti a debreceni repülótér mint az egyik legjelentösebb egykori szovjet katonai ingatlan fejlesztését. Másrészt „A természeti és épitett környezet fejlesztése és védelme" prioritásban tervezik a barnamezös ipartelepek rehabilitációját, és az indoklásban a volt katonai használatú ingatlanok hasznositása is szerepel. Az intézkedés tartalmazza „a területek tulajdonviszonyának rendezését, a környezeti kármentesitést (feltárás, müszaki beavatkozás, utólagos ellenörzés), a területek funkcióváltását, a település szövetébe való bekapcsolásukat, a zöldmezös beruházások területigényének csökkentését, a leromlott állagú épületek bontását, az infrastruktúra-fejlesztéseket, olyan terület-elókészitéseket, amelyekkel a területen az új funkciójú ipar vagy a lakófunkció megjelenik.

Debrecen Integrált városfejlesztési stratégiája (Euro-Régió Ház 2008) már alig foglalkozik a barnamezős területekkel mint egységgel (egyedül a Nyugati Ipari Parkot említi mint barnamezős ipari parkot), ugyanakkor több helyen is tárgyalja a korábbi szovjet katonai területek jövóbeli helyzetét. „A városrészekhez kapcsolódó célok" alfejezetben a Villanegyed vonatkozásában fontosnak tartja az Informatikai Kar épületének beruházását a Kassai úton, ami a Szilícium Mező projekt kulcselemének számit, illetve az Egyéb övezetek részben a debreceni repülötér intenzívebb kihasználását szorgalmazza.

\section{A szovjet katonai objektumok sorsának alakulása a városban}

A terepi vizsgálat során különböző módszereket alkalmaztunk. Egyrészt felhasználtuk a létesítmények 1990-1991-es átadásakor készített dokumentumokat, amelyek összesen 14 ingatlant említettek. Másrészt személyes interjúkat folytattunk, harmadrészt felkerestük az egykori szovjet katonai ingatlanokat, és egy általunk készített adatlap segítségével azonos szempontok alapján rögzítettük legfontosabb jellegzetességeiket.

\section{A sikeresen - legalább 90\%-ban - megújult objektumok}

\section{A repülótér lakóházas, intézményi területe (2)}

A reptér üzemi részétől északra elhelyezkedő kb. 23 hektáros területen a második világháború előtt csak néhány épület helyezkedett el, ugyanakkor a 
1. ábra: Debrecen volt szovjet katonai objektumai

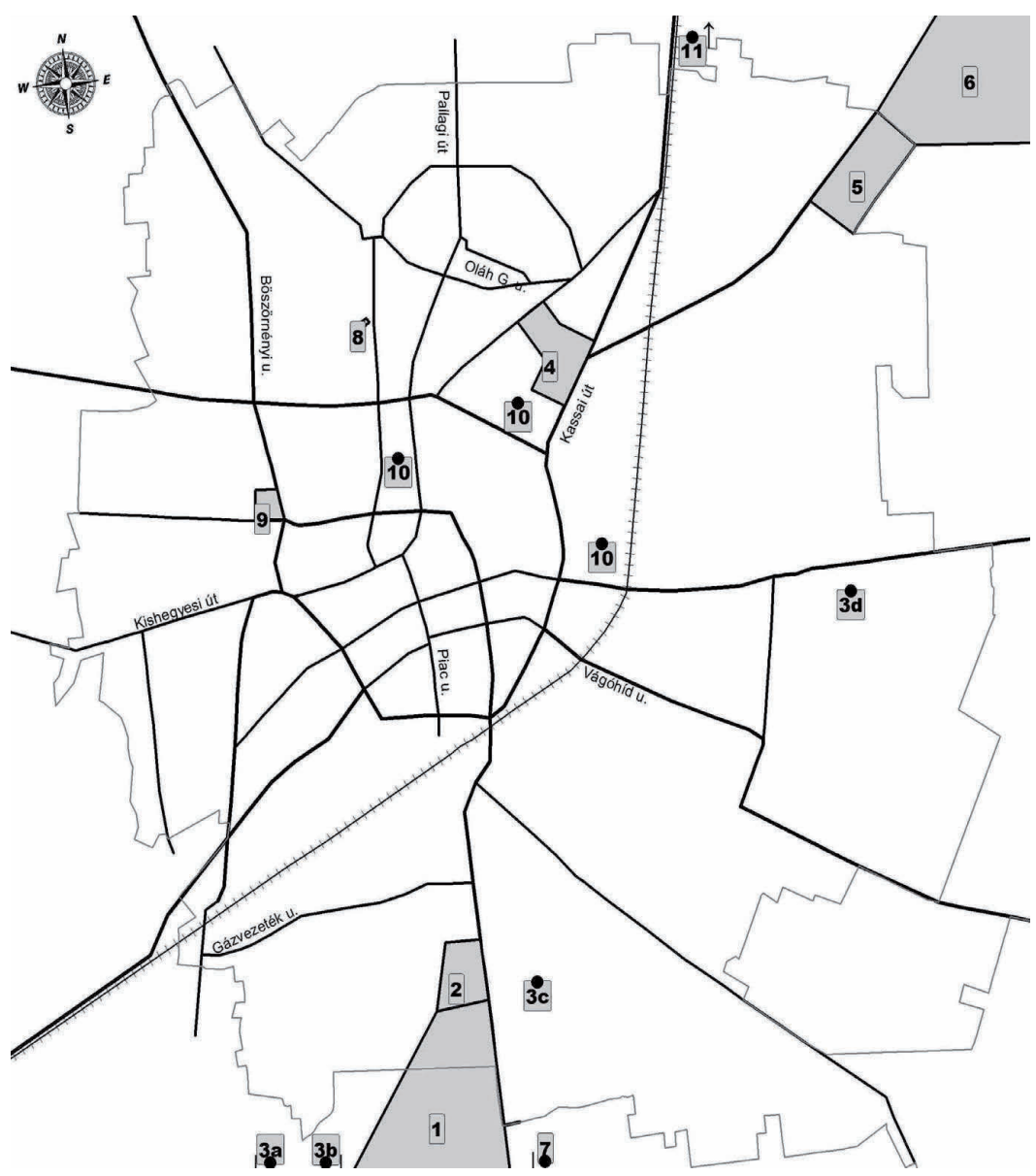

Megjegyzés: Az egyes számok a bemutatott objektumokat jelölik, a megfelelo" számok az alcímek mögött zárójelben találhatók.

Szerkesztette: Kozma Gábor, Németh Gábor, Debreceni Egyetem (2011).

szovjet csapatok az 1950-es évektől kezdve igen jelentős beruházásokba kezdtek, amelyek során 52 téglaszerkezetü, panelos és blokkos lakóépületet, valamint több kiszolgálóépületet (például iskolát, üzletet, gyengélkedőt, művelődési otthont) építettek. Az ingatlanokat először a ZÁVKHI ${ }^{2}$ vette át, majd a Magyar Honvédség kezelésébe kerültek, később pedig ingyenes vagyonátadás során az önkormányzat szerezte meg a tulajdonosi jogot. A felmérések szerint az átadáskor az épületek müszaki állapota sehol nem érte el a 70\%-os szintet, többnyire 40-50\%-ra értékelték azokat, de akadt olyan is, amelynek 0\%-os volt az állapota, vagyis hasznosításra teljességgel alkalmatlannak bizonyult. 
Az ingatlanok közül a leggyorsabban az egykori iskola sorsa rendeződött: tekintettel a déli városrész oktatási intézményeinek kedvezőtlen helyzetére, az épületet már 1991-ben felújították, azóta többször modernizálták (például tornateremmel látták el), és jelenleg is oktatási funkciókat lát el. A lakóépületek renoválása - a szükséges pénzügyi erőforrások hiánya miatt - csak lassabban haladt előre: egy részüket az önkormányzat eladta, így ezeket az új tulajdonosuk újította fel. A fennmaradók modernizálására a Széchenyi-terv keretében került sor, és a későbbiekben ezeket az önkormányzat mint szociális bérlakásokat hasznosította. Az egykori lakótelepi rész harmadik egységét az önkormányzat által az 1990-es évtizedben értékesített üres terület alkotta, amelyen az elmúlt években több mint 10 magas komfortfokozatú társasház épült fel.

\section{A Kassai úti laktanya (4)}

A Kassai (volt Szabadság) úti objektum a századfordulón épült magyar huszár-, illetve tüzérlaktanyának, Vilmos laktanya néven (a második világháború után mint Gábor Áron laktanyát tartották nyilván). Területén 1925-ben még 32 kisebb-nagyobb épület állt, amelyeknek a fele áldozatul esett a második világháborús bombázásoknak. A szovjetek az 1950-es években költöztek a müemlék jellegü ingatlanokba, a területet kb. 50\%-kal bővítették, és új épületeket is emeltek (az átadási dokumentáció alapján szám szerint tizenkilencet). Az átadás-átvétel során a terület a magyar állam tulajdonába került, az 1990-es évek második felében ugyanakkor a kezelői jogot a Debreceni Universitas Egyesület kapta meg, amely a debreceni felsőoktatás területi kiterjedésének legfontosabb zálogaként kezelte az ingatlant.

Az objektum hasznosítása alapvetően négyfajta módon ment végbe. Egyrészt a szovjetek által emelt épületek nagy részét elbontották, napjainkra csak néhány maradt meg közülük. Másrészt az 1990-es években világbanki, uniós és egyetemi forrásokból megkezdődött a hasznosítható épületek felújítása. Ezekbe költözött be a Debreceni Egyetem Állam- és Jogtudományi, Közgazdaság- és Gazdaságtudományi, valamint Népegészségügyi Kara, a Tudományegyetemi Karok Gazdasági Igazgatósága, az Egyetem Gazdasági Főigazgatósága. Harmadrészt az egykori lovardában kulturális és konferencia-központot alakítottak ki. Végül a rendelkezésre álló jelentős nagyságú szabad területen új beruházások indultak: világbanki forrásból épült fel az új Társadalomtudományi Oktatási Központ és Társadalomtudományi Szakkönyvtár, PPP-konstrukcióban az új kollégium (Campus Hotel) és az Európai Unió támogatásával (TIOP 1.3.1-07/2) jelenleg is folyik az Informatikai Kar beruházása, amely a Debreceni Fejlesztési Pólus Szilícium Mező kulcsprojektjének legfontosabb eleme.

\section{Paci-erdei bombaraktár (7)}

A repülőtéren állomásozó repülőgépek fegyverzetének tárolására a város külterületén, az úgynevezett Paci-erdőben, egy 7,8 hektáros területen a szovjet 
hadsereg 1952-ben 6 egységből álló bombaraktárt hozott létre. A város 1991ben a mintegy $200 \mathrm{~m}^{2}$ nagyságú, vasbeton szerkezetü raktárrendszerrel kapcsolatban két forgatókönyvet készített: az egyik szerint a terület - az erdő visszaállítása történt volna meg, teljes zöldfelületi rehabilitációval (a raktár bontásával), a másik terv szerint a raktárt a Vekeri-tavi kirándulóközpont elemeként (pl. tárolásra) használták volna (Beszámoló 1991). A két elképzelésből alapvetően a második valósult meg. A magántulajdonba került területen az egykori katonai épületek jelentős részét elbontották (jelenleg csak egy földdel burkolt beton-bombaraktár és néhány szovjet eredetű kiszolgálóépület emlékeztet a korábbi használókra), az ingatlan pedig mint szabadidőközpont müködik (Vígkend major): szálláshelyek, éttermi és konferenciaszolgáltatások vehetők igénybe, sportpályák bérelhetők, valamint itt kaptak helyet a rendszerváltás után a városból kiköltöztetett munkásmozgalmi szobrok.

\section{Nagy Lajos király téri hírközpont és lakások (8)}

Az ingatlanon található első épületek még a második világháború előtt épültek, majd az 1950-es években szovjet használatba került objektumban további beruházásokat hajtottak végre (például garázsok, raktárak, őrépületek épültek). A rendszerváltás után önkormányzati tulajdonba átadott telek hosszú ideig kihasználatlan volt (egy ideig hajléktalanok vették birtokba), majd az 1990-es évek második felében magánbefektetők tulajdonába került. $\mathrm{Az}$ újrahasznosítás során a terület korábbi lakó- és üzemi építményeit lebontották, és a 2000-es évek elején új épületet emeltek a helyükre, amelyben több mint 20 lakás mellett a Technika Háza és több üzlethelyiség (például Spar áruház) is található.

\section{Bérelt lakások: Öszirózsa köz, Landler és Apafi utcák (10)}

A szovjet csapatok a laktanyák területén kívül is béreltek lakásokat, szám szerint 75-öt, amelyek az Őszirózsa közben, a Landler utcában és az Apafi utcában voltak. Az egyszobás lakásokat a szovjetek a Debreceni Ingatlankezelő és Közvetítő Vállalattól vették bérbe. A lakások közül mindössze 13 volt komfortos (a többi félkomfortos), átlagosan $35 \mathrm{~m}^{2}$ alapterületen. Mindegyik lakás állapota - még a megkímélteké is - kritikus volt az átvétel idejében, teljes felújításra szorultak. A felújítást követően a lakásokat magánszemélyek részére értékesítették.

\section{Részben megvalósult, illetve folyamatban lévó rehabilitációk}

\section{A repülótér üzemi része (1)}

A szovjet csapatok által használt legjelentősebb katonai ingatlan - a repülőtér tulajdonképpen három különböző típusú és funkciójú területet foglalt magában: az üzemi részt, a lakótelepi részt és az irányadó állomásokat. A repülőtér 
üzemi részét már a II. világháború alatt is a katonaság használta, magyar és német repülős egységek állomásoztak az objektumban. Az 1960-as évekig volt egyidejűleg magyar polgári és szovjet katonai használatban, majd az 1960-as évektől a szovjetek fokozatosan kiszorították a magyar polgári repülést. A területen az 1950-es évektől számtalan funkciójú épületet létesítettek a szovjetek: a kifutó- és gurulópályák, kiszolgálóépületek mellett tárolók, raktárak, iszapkezelő, egészségügyi labor, óvóhelyek és fedezékek épültek.

Az ingatlant 1990-ben vette át a Magyar Honvédség Fenntartási és Elhelyezési Főigazgatósága, majd 1994-ben a Kincstári Vagyonkezelő Szervezettől a helyi önkormányzat vásárolta meg.

Az objektum fejlesztése és működtetése a kezdetektől fogva igen jelentős összegeket igényelt, ennek következtében a helyi önkormányzat intenzíven törekedett a magánszféra bevonására, törekvései azonban eddig nem jártak sikerrel. 1997-ben a magyar Szer-Bon Rt-vel, 1998-ban a török BEGENDIK GROUP cégcsoporttal, míg 2008-ban a magyar Xanga Holding Zrt-vel kötött a város ilyen irányú szerződést, a partnerek azonban rövid időn belül mindhárom esetben felbontották azt, így jelenleg is a város tulajdonában álló Airport Debrecen Kft. üzemelteti az objektumot.

A fentiek tükrében nem meglepő, hogy a repülőtér sikeres működtetéséhez szükséges beruházásokat a helyi önkormányzat kénytelen volt döntő mértékben saját erejéből finanszírozni. A kb. 4 milliárd Ft értékủ fejlesztések többek között az alábbi területekre terjedtek ki: korszerü navigációs berendezés beszerelése, parkoló megépítése, a nemzetközi biztonsági előírásoknak megfelelő fegyveres védelem és járőrözés kialakítása, a fogadóépület bővítése, tűzoltójárművek beszerzése, a terület kármentesítésének végrehajtása (ez utóbbi beruházást az I. Nemzeti fejlesztési terv Környezet és infrastruktúra operatív programjának keretében az Európai Unió 818 millió Ft-tal támogatta). A beruházások következtében a Debreceni Nemzetközi Repülőtéren (2004. április 22től) a magyarországi vidéki repülőterek közül egyedüliként létesült állandó vámút és nemzetközi légi határátkelőhely. 2008-ban schengeni légi határátkelőhely létesült, és a minősítések alapján a légikikötő hatósági szempontból egyenrangúvá vált a Budapest Ferihegy Nemzetközi Repülőtérrel. A repülőtér forgalmát az 1990-es évtizedben még elsősorban a kisméretü gépek jellemezték, a fejlesztések hatására ugyanakkor az új évezredben egyre fontosabb szerepet játszanak a közép- és nagyméretű személyszállító repülőgépek. A térség korlátozott fizetőképessége, valamint szervezési problémák miatt azonban a menetrendszerü járatok csak rövid ideig közlekedtek (az útirányok Bécs, München és Budapest voltak), míg a nyári idegenforgalmi desztinációkat megcélzó charter-járatok száma a világgazdasági válság következtében a 2006-2007-es évhez képest 2010-re jelentősen (7 célpontról 3 célpontra) csökkent.

A repülőtér másik lehetséges hasznosítása lehetőségét - a légi fuvarozást a térség gyenge gazdasági ereje miatt az elmúlt 20 évben alig használták ki. A 
helyzet javítása érdekében a helyi önkormányzat 2010-ben a Saigo Port Kftvel egy cargo- és logisztikai bázis megvalósítására kötött szerződést, amelyben a cég vállalta, hogy a repülőtér egy részének 99 évre szóló bérlése ellenében logisztikai kiszolgálócsarnokokat épít az ingatlanon.

\section{Irányadó állomások (3a, 3b, 3c, 3d)}

A repülési technika fejlődése az 1950-60-as évektól kezdve szükségessé tette a repülőgépek fel- és leszállását segito irányadó állomások felépitését, amelyek a kifutópálya vonalában, attól északkeletre és délnyugatra helyezkedtek el. A repülőtér városon belüli fekvése következtében az úgynevezett északi közeli és távoli irányadó állomás a település belterületére esett, míg a déli objektumok már külterületen (közülük az egyik ugyanakkor a Debrecen lakott külterületének számító Szepes határában) helyezkedtek el. Az irányadó állomások az adóházak és a személyzetet elszállásoló lakóépületek mellett kutakat, melléképületeket, tárolókat, aggregátorházakat foglaltak magukban (ez utóbbiakra a lakott területtól távol fekvő ingatlanok esetében volt szükség), de a rendszerváltáskor tapasztalt silány müszaki állapotuk, speciális jellegük, illetve fekvésük nem tette lehetővé renoválás utáni újrahasznositásukat.

Az irányadó állomások a repülőtér 1994-ben történt megvásárlása során a helyi önkormányzat tulajdonába kerültek, sorsuk azonban eltérő módon alakult. A déli távoli állomás (3a) korábban a szántóföld közepén helyezkedett el, így nem meglepő, hogy az önkormányzattól magántulajdonba kerülés után elbontották, és jelenleg a területet mezőgazdasági célra hasznosítják. A déli közeli állomás (3b) - mint már utaltunk rá - Szepes határában helyezkedett el; helyén a lebontás és tulajdonosváltás után napjainkban egy újonnan épített raktárhelyiség és egy lakóház található.

Az északi közeli irányadó állomás (Szávay utca) (3c) hasznosítása nem történt meg: a jelenleg is önkormányzati tulajdonú, kerítés nélküli ingatlanon kertes házak között két romos állapotú egykori irányadó épület fekszik, és sem a kialakított betonutakat, sem a járdákat nem szedték fel. Az északi távoli állomást (Lahner - Asztalos utca) (3d) elbontották, a helyén 10 új sorház épült, ami nagyjából 35-40 új lakást jelent.

\section{Sámsoni úti (Esze Tamás) lakłanya (5)}

A Sámsoni úti volt szovjet páncéloslaktanya 26,6 hektáros területe korábban a város külterületén helyezkedett el. A szovjetek csak az 1960-as években költöztek be, és fokozatosan kialakították a számukra szükséges infrastruktúrát (a kivonuláskor készített helyszínrajz szerint összesen 106 különböző építmény helyezkedett el az ingatlanon: lakó-, őr- és oktatási épületek, harcijármü-tárolók, óvoda, kazánház stb.). A város tervei között 1991-ben az objektumok helyén autópiac, nagybani piac és tehergépjármü-tároló kialakítása szerepelt, majd 2004-ben egy lakópark létesítése is felmerült, a tervekből azonban mindmáig semmi nem valósult meg. 
Az ingatlan jelenlegi hasznosítása igen változatos. A szovjet csapatok kivonulása után a jobb minőségű lakások magántulajdonba kerültek, míg a többi terület állami tulajdonban maradt. Az utóbbin egy menekülttábor, egy rendőrségi fogda (felújítva uniós támogatásból 2006-ban), valamint a Bevándorlási és Állampolgársági Hivatal Észak-alföldi Regionális Igazgatósága működik; emellett igen jelentős terület hasznosítása még nem megoldott.

\section{Böszörményi úti ruharaktár és laktanya (9)}

Az 1,3 hektáros ingatlan épületeit a II. világháború előtt kereskedelmi, raktározási célra használták, később nyerte el ruharaktár- és laktanyafunkcióját. A raktárt egy időben mind a magyar, mind a szovjet fél használta. A kiürítést követően a Kenézy Kórház nyújtotta be igényét az épületekre, raktári célú felhasználásra, illetve gazdasági ellátórészleg építésére - ez a mai napig nem történt meg.

Jelenleg a terület állami és honvédségi tulajdonban van, új hasznosítóként kereskedelmi és szolgáltató vállalkozások költöztek az építményekbe, de van olyan épület, amely továbbra is a honvédség katonai ruharaktáraként funkcionál. A négy egyszintes szovjet épületet renoválták, garázsok és raktárak találhatóak bennük, a három (háború előtt épült) magyar épületnek csak az alsó szintjén történt homlokzati felújítás - ide költöztek a vállalkozások -, a felső szintek változatlan formában állnak 1991 óta, bár azokat egy kivételével továbbra is használják. 2004-ben a debreceni önkormányzat a Hajdú-Bihar Megyei Levéltár részére, raktározási célokra megigényelte az épületek egy részét a Honvédségtől (HM Szemle 2004). Kormányzati pályázati forrásokból kívánták finaszírozni, de tényleges építkezés nem történt.

\section{Mind ez idáig sikertelen hasznosítású területek}

\section{Sámsoni úti gyakorlótér (6)}

A Debrecenben állomásozó harckocsizó-egység gyakorlótérként a laktanyától északkeletre elhelyezkedő, kb. 146 hektáros területet használta, amely jelenleg állami tulajdonban van. A gyakorlótér újrahasznosítása a szovjetek 1991es távozása óta nem indult el: bár a város terveiben többféle új funkció is szerepelt: stadion, neutronkutató, lakópark, végül egyik sem valósult meg. Ez alapvetően azzal indokolható, hogy a területen semmilyen kiépített infrastruktúra nincs, elhanyagolt (a betonutak és építmények egy része jelenleg is megtalálható), és a taposással, bombagödrökkel okozott károkat sem hárították el. A fentiek mellett problémát okoz az is, hogy a lakosság a gyakorlótér egy részét kommunális hulladék lerakására használja.

\section{Apafai lószerraktár (1 1)}

A 3,5 hektáros, több szovjet épülettel rendelkező terület egy részén a szovjetek kivonulását követő 10 éven keresztül tűzszerészeti és környezeti kármen- 
tesítés sem történt. Erre 2001-ben kerülhetett csak sor, amikor az ÁPV Rt. közbeszerzési pályázatát az Eurimex Kft. elnyerte. A terület hasznosítására legutóbb 2009-ben tett javaslatot a lőszerraktár mellett üzemelő Debreceni Lövészegylet, amely lőpályákat kívánt a helyszínen kialakítani.

\section{A hasznosítás jellegzetességei Debrecenben}

A vizsgálatba bevont 14 debreceni objektum jelenlegi helyzetét tekintve alapvetően kedvező tendencia figyelhető meg, ami azt jelenti, hogy csak négy ingatlan esetében nem indult el semmilyen hasznosítás 2010-ig (ebből kettő irányadó állomás), ami az összes volt szovjet terület (652 ha) 23\%-a. A négy nem hasznosított ingatlanból kettő külterületi és egy hármas ${ }^{3}$ típusú, vagyis azokhoz az ingatlanokhoz tartozik, amelyek hasznosítása országosan is lassan és nehézkesen indul be. Ennek egyik oka a periferikus elhelyezkedés, a kiépítetlen infrastruktúra, a nagy kiterjedés, az állami tulajdon és az a tény, hogy a területet nem felparcellázva, hanem általában egészben kívánják értékesíteni, ami igencsak leszűkíti a beruházási lehetőségeket.

Négy ingatlanról mondható el, hogy teljes egészében megújult, területén a rehabilitáció befejezettnek tekinthető. Ebből egy a 3 bérházból álló csoport (75 lakással), egy a volt hírközpont, szintén többnyire lakáscélú hasznosítású, kettő irányadó központ (lakáscélú hasznosítással). Az ingatlanokból csupán egy adótorony nem centrális elhelyezkedésü, az északi távoli jeladó. A befejezett hasznosítás aránya az összes területnek mindössze 2 ezrelékét teszi ki, vagyis 1,6 hektárt. Abban az esetben azonban, ha a nagy területű lőteret - amelynek hasznosítása nehézkes - kivonjuk az összes területből, akkor az arány 3,2 ezrelékre javul, amely még így sem tekinthető jelentősnek. Az összes ingatlanra vetítve átlagosan 62,5\%-os a hasznosítás foka.

Debrecen egyik jellegzetessége, hogy a szovjetek igen nagy számú épületet emeltek az objektumokban (legalább 170-175-öt), amelyeknek egy részét „feketén”, magyar hatósági engedélyek nélkül húzták fel. Ezeket a kiürítést követően nem sokkal lebontották, de a megmaradt, jobb állapotú épületeket többnyire sikerrel tudta a város hasznosítani, amelyre igen jó példa a Mikepércsi-lakótelep 608 felújított lakása.

A szennyezettséget tekintve szerencsésnek mondható a város, hiszen minden ingatlan esetében megtörtént a kármentesítés, napjainkra már csak egy-két objektum területén fordul elő minimális kommunális hulladék. Az Apafa utcai lőszerraktárt utolsóként kármentesítették a városban, ami megmagyarázhatja annak elhúzódó hasznosítását - ezen túlmenően a szennyezettség sehol nem szabott gátat a mielőbbi hasznosításnak.

Az új funkciók szinte minden megjelenési formájával találkozhatunk az ingatlanoknál. A 14 objektum közül haton (42\%) alakítottak ki felújítással és 
új építéssel lakásokat, szám szerint megközelítőleg 900-at, ami mintegy 2700 új lakót jelent a területeken. A hasznosítás ugyancsak gyakori formája a kereskedelmi, szolgáltatási funkció, ezzel 5 objektumon (35\%) találkozunk. Az intézményi hasznosítás 4 ingatlanon (28,5\%), a mezőgazdasági, oktatási (kulturális) és sporthasznosítás 1-1 ingatlannál fordul elő. A Böszörményi úti ruharaktár egyedülálló helyzetben van: a szovjetek idején már használta a Magyar Honvédség, és a kivonulás után továbbra is változatlan formában használja egy részét. A területek nagyságát tekintve az összes új funkció közül 30\%-on alakítottak ki kereskedelmi, szolgáltatási és gyártóegységeket, 48\%-on lakásokat, 19\% kapott közigazgatási és oktatási, 3\% pedig kulturális funkciót.

A felhasznált forrásokat tekintve az ingatlanok 64\%-ánál magántőke, 36\%-ánál önkormányzati forrás segített a területek megújulásában. Uniós forrásokat (TIOP, KIOP) csak az ingatlanok 21\%-ánál használtak fel. 14-ből 8 objektum van, amelynek egésze vagy része magántulajdonba ${ }^{4}$ került (57\%), 43\% esetében pedig elmondható, hogy részben, egészben önkormányzati tulajdonban van. A négy teljes egészében megújult objektum mindegyike magántulajdonba került.

Az objektum környezetének fizikai megújulása, javítása (parkosítás, füvesítés, tereprendezés, új utcai bútorok elhelyezése stb.) a 14-ből csak 8 esetben történt meg, vagyis az ingatlanok 57\%-án, de a teljes területnek csak a 41\%-án. Sikeres (jól funkcionáló, tartós, igényes, hosszú távon nyereséges és a kitüzött célokat elérő) rehabilitációról 8 esetben beszélhetünk, ami az összes terület $72 \%$-át jelenti.

\section{Összefoglalás}

A szovjetek hazánk megszállása alatt a katonai objektumokat eltérő célokra használták, gyakorlóterek, laktanyák, óvodák, tiszti klubok, harckocsi-javítómühelyek egyaránt megtalálhatóak köztük. Közös bennük, hogy a csapatkivonásokat követően kiderült: ezen épületek állaga kritikus, a területek szinte minden esetben súlyosan károsodtak a katonai használat során, jó néhány épületet nem a magyar szabványoknak megfelelően építettek fel, így azok - bár „ingyenesen”, az okozott károk fejében kerültek az állam tulajdonába - a barnamezők körét gyarapították hazánkban. A kiürítést követően az állam, majd a tulajdonos helyi önkormányzatok szembesültek azzal, hogy ezeket a területeket csak alapos átvizsgálás, kármentesítés után lehet hasznosítani, illetve értékesíteni, és akkor is nehezen, hiszen ingatlanpiaci besorolásuk más, zöldmezős, illetve rendezett városi területeken álló ingatlanokhoz képest kedvezőtlenebb. A területek egy részén spontán átalakulás ment végbe, a kiürítést követően röviddel új tulajdonos vagy bérlő hasznosította azokat, de ez csak az esetek kisebb részére jellemző. Sok ingatlan a mai napig őrzés alatt áll, hasznosítása ideiglenesen sem történt meg. 
Több megyeszékhely elemzése rámutatott arra, hogy hazánkban a volt laktanyákat - legyenek azok szovjet vagy magyar objektumok - gyakran nem sorolják a városok barnamezős területei közé, annak ellenére, hogy azok a barnamezők számos tulajdonságával rendelkeznek: szennyezettség, rendezetlenség, alulhasznosítottság, illetve mozaikos hasznosítás, problémás hasznosíthatóság (állapotuk és tulajdonosi szerkezetük miatt). Tekintve, hogy sokszor nem nevezik meg a volt (felhagyott) ipari területek közt, így újrahasznosításuk, felszámolásuk sem kap minden esetben prioritást. Bár Debrecen a szovjet laktanyák megújítását a város 2006-os fejlesztési programjában prioritásként kezeli, a 2008-ban készült IVS csak az objektumok töredékével kapcsolatban tartalmaz elképzeléseket.

Néhány megyeszékhely - Győr, Szolnok - összehasonlításából (Kádár 2008, 2010b) kiderül, hogy bár ezekben a felhagyott objektumok újrahasznosítása szinte 100\%-ban megindult, a területek hasznosításának aránya mégsem ezekben a legnagyobb, hanem Debrecenben, ahol a legnagyobb számú ingatlan található. A vizsgált objektumok egyikén sem történt olyan önkormányzati, regionális vagy állami forrásokból finanszírozott előkészítés - lásd például az észak-francia modellt, ahol a telephelyeket előzetes tisztítás, tereprendezés után kínálják fel a befektetőknek hasznosításra (Grimski, Ferber 2001), amely jelentősen megkönnyítette volna a területeknek a várostestbe történő visszavezetését. A magántőke a megújulásban fontos szerepet játszott mind Győr, mind Szolnok esetében. Az önkormányzati szerepvállalás a második legfontosabb tényező volt a területek átalakulásban, a harmadik helyen pedig a bevont uniós források állnak.

Összességében a debreceni objektumok átalakulása, funkcióváltása sikeresnek mondható a másik két megyeszékhellyel történő összevetés alapján, hiszen a szovjet építmények, ingatlanok mind számban, mind területnagyságban megelőzik azokét. A sikeres megújulásnak ebben a városban fontos tényezője volt a regionális szerepkör növelése: az egyetemi funkciók bővítése, modernizálása és a nemzetközi repülőtéri feladatok felvállalása, ami két nagyobb katonai terület rehabilitációjához járult hozzá. Itt is (mint a többi megyeszékhely esetében is) kedvezett a belvárosi, belterületi elhelyezkedés a hasznosítás során, és akárcsak a többi megyeszékhelyen, a területek átalakulása többnyire spontán indult be, egyrészt az ingatlanpiaci igényeknek, folyamatoknak megfelelően, másrészt a város azon felismerése alapján, hogy a mủemléki, illetve értékes belvárosi területek átalakulása hozzájárul Debrecen városképének, gazdaságának fejlődéséhez.

A legproblematikusabb területek közé Debrecenben is a lötér és a harckocsi-gyakorlótér tartozik, valamint a városban kis területen, elhagyottan álló volt irányadó épület. Az előzők hasznosítása elhelyezkedésük, kiterjedésük miatt nehézkes. A kisebb terület befektetésre történő előkészítése, funkcióváltásának elősegítése azonban nem igényelne a várostól túlzott mértékű forrásbevonást. A reptér üzemi részén még mindig nagy terület nem került 
rehabilitációra: napjainkban is áll még néhány „szellemépület” a fogadóépületek szomszédságában, köztük egy 20 lakásos betonépület váza. Romos állapotban, építési törmelékkel körbevéve egy több száz négyzetméteres volt raktárépület is hasznosítatlanul áll, kihasználatlan az egykori hangárok döntő része, és a reptér melletti egykori sportpálya sem újult meg (a legújabb elképzelés szerint ezen a helyen létesülne a város harmadik TESCO-áruháza). Ezen területek a befektetői érdeklődés hiánya miatt csak önkormányzati forrás bevonásával, a területek előzetes tisztításával, előkészítésével újulhatnak meg az elkövetkező évtizedben, ehhez azonban szükség lenne a volt katonai területeknek a prioritások közé emelésére a legfontosabb városfejlesztési dokumentumokban.

\section{Jegyzetek}

1 1957. évi 54. törvényerejű rendelet a Magyar Népköztársaság Kormánya és a Szovjet Szocialista Köztársaságok Szövetségének Kormánya között a Magyar Népköztársaság területén ideiglenesen tartózkodó szovjet csapatok jogi helyzete tárgyában Budapesten 1957. május 27-én aláírt egyezmény kihirdetéséről, 12. cikk.

2 Zárolt Állami Vagyont Kezelő és Hasznosító Intézmény

3 1. típus: laktanyák, irodák, szolgáltatóhelyiségek. 2. típus: kiképző-, műszaki és raktárépületek 3. típus: lőterek, gyakorló- és repterek. A három típushoz tartozó ingatlanok a kiépített közművek, infrastruktúra, beruházási lehetőségek stb. alapján eltérő mértékben válnak hasznosíthatóvá (Kádár 2010a)

4 Ezen magánemberek, egyéni, illetve társas vállalkozások tulajdonát értjük.

\section{Irodalom}

Balcsók I., Koncz G. (2006): Debrecen. In: MTA RKK KÉTI: Zöldmezős és barnamezős beruházások a magyar nagyvárosokban. Témavezető: Győri Róbert, Budapest

Csapody T. (2000): Landmines in Hungary. A gyalogsági aknák Magyarországon. Országjelentés a Landmine Monitor részére. MTA Politikai Tudományok Intézete, Budapest

Debrecen Megyei Jogú Város (1995): Déli Városrész, repülőtér és térsége általános rendezési tervének módosítása. Fejlesztési és Rendezési program, Debrecen

Debrecen Megyei Jogú Város Fejlesztési Programja 2007-2013: (2006) Helyzetfeltárás. Debrecen

Debrecen Megyei Jogú Város Polgármesteri Hivatala Építési és Közlekedési Osztály (1991): Beszámoló a szovjet ingatlanok ügyében a folyó év február 21-én tartott megbeszélésről. Debrecen

Debrecen Megyei Jogú Város Polgármesteri Hivatala Építési és Közlekedési Osztály (1991): Előterjesztés a debreceni repülötérhez tartozó lakásokra történö igénybejelentésről. Debrecen

Grimski, D., Ferber, U. (2001): Urban brownfields in Europe. Land Contamination and Reclamation, 1., http://eppdocs.books.officelive.comDocuments09-1-14.pdf (2010. 04.12.)

Euro-Régió Ház Kft. (2008): Debrecen Megyei Jogú Város Integrált Városfejlesztési Stratégiája. Tervezet. Debrecen

Farkas A. (2009): A Debreceni Nemzetközi Repülötér bemutatása. Airport Debrecen Kft. www.airportdebrecen.hu (2010. 10. 18.) 
Hadtörténelmi Levéltár (2006): A dolgozó népet szolgálom! Forráskiadvány a Magyar Néphadsereg Hadtörténelmi Levéltárban őrzött irataiból, 1957-1972. TONYO-GRÁF Nyomdai és Grafikai Stúdió, Budapest

HM Zrínyi Kommunikációs Szolgáltató Kht. (2004): Szemle. Napi válogatás a sajtóból. (2004. 01. 19.)

Homor Gy. (2009): Szovjet csapatkivonás térségünkból. Jókai Mór Városi Könyvtár Kötészeti és Sokszorosító Mühelye, Pápa

Kádár K. (2008): Felhagyott szovjet katonai objektumok hasznositása Szolnokon. MTESZ Jász-NagykunSzolnok megye, Szolnoki Tudományos Közlemények, Szolnok

Kádár K. (2010a): Szovjet katonai objektumok újrahasznosítása a városrehabilitáció során, a megyeszékhelyeken. Abszolutóriumi dolgozat, PTE KTK, Pécs

Kádár K. (2010b): Urban rehabilitation realised by the reuse of Soviet military sites in two Hungarian county seats. Pécsi Tudományegyetem Regionális Politikai és Gazdaságtani Doktori Iskola. Félidőben Konferencia, Pécs (megjelenés alatt)

Keletterv Kft. (2000): Debrecen Megyei Jogú Város településszerkezeti terve. Debrecen

Kincstári Vagyonkezelő Szervezet szerződése (n. d.) Debrecen Megyei Jogú Város Önkormányzatával, a debreceni szovjet repülőtér és rádiótechnikai állomás eladásáról, Debrecen

Magyar Honvédség Fenntartási és Elhelyezési Főigazgatósága (1990): Jegyzőkönyvek a VA alakulatok által használt ingatlanok átadás-átvételére. Reptér és laktanyai rész, irányadó állomások, reptér üzemi része. Debrecen

Nagyházi T. (1991): Jelentés a Polgármester Úr részére a Sámsoni úti laktanya terület-vizsgálatáról. Debrecen

Ránki Gy. (1976): A második világháború története. 2. kiadás. Gondolat Kiadó, Budapest

VÁTI Keletterv Kft. (2000): Debrecen településszerkezeti terve. Debrecen

VÁTI Kht. Településtervezési és Tájtervezési Irodája (2003): Az EU strukturális alapok keretében barnamezős rehabilitációra kiírandó pályázatok szakmai megalapozása. (Előkészítő tanulmány). Témafelelős: Nagy Ágnes. Budapest

VITUKI Környezetvédelmi és Vízgazdálkodási Kutató Intézet Kht. (2005): Az Országos Környezeti Kármentesitési Program Alprogramjai. „Tájékoztató összefoglalás az 1997 és 2004. közt elvégzett feladatokról" http://www.kvvm.hu/szakmai/karmentes/alprogram/alprogramok.pdf. (2010. 01.15)

Debrecen Megyei Jogú Város (2003): Helyi épitési szabályzat és szabályozási terv. 8/2003.(V. 23.) Kr. Rendelet, Debrecen

Debrecen Megyei Jogú Város (2010): 9/2010. (II. 23) Önkormányzati rendelet a 8/2003.(V. 23.) Kr. Rendelet módosításáról, Debrecen 